\title{
KISVÍZGYÜJTŐKÖN LEJÁTSZÓDÓ EXTRÉM CSAPADÉKESEMÉNYEK TÉRINFORMATIKAI VIZSGÁLATA
}

\author{
Dobai András \\ PhD hallgató, Miskolci Egyetem, Földrajz-Geoinformatika Intézet \\ 3515, Miskolc,Miskolci-Egyetemváros, email:ecodobai@uni-miskolc.hu
}

\begin{abstract}
Absztrakt
Az árvizi védekezések során fontos szempont, hogy a védelmi feladatot ellátók teljeskörü információval rendelkezzenek, a fö védvonalak mellett, azokról az árvízben érintett területekröl is, amelyeken vízkár okozta idöszakos akadályok (pl.: vizátfolyások) jelenhetnek meg. Ezek a jelenségek érinthetnek utánpótlási útvonalakat vagy kihathatnak a lakosság közhangulatára és figyelmet vonhatnak el a védekezés során. Így fontos, hogy a szakemberek tisztában legyenek a jelenség körülményeivel és várható hatásaival. Jelen tanulmány a 2020 október hónap folyamán lezajló árhullám egyik jelenségét elemzi és a térinformatika eszközével próbálja bemutatni, valamint megmagyarázni annak kialakulási körülményeit. A cikkben bemutatott módszertant szeretném a doktori értekezésemben alkalmazni és fejleszteni, hogy megbizható hátteret tudjak nyújtani a környezeti modellezésekhez.
\end{abstract}

Kulcsszavak: elméleti lefolyásmodell, időszakos vízfolyás, Sajó-folyó

\begin{abstract}
During a flood event, it is essential to know complete knowledge about the whole study area of protection for managing a flash flood. This may include areas that could be affected by the flood damage (e.g. water flows), but could also be far from main embankments. Furthermore, this phenomena could be of risk to supply routes or affect the population's well-being, which could distract the overall defence management. Thus, the present study will present, analyze, and quantify one of the flood events of October 2020 and understand its formation using ArcGIS 10.7.1. This methodology will be expanded during my doctoral research by applying terrain and environmental covariates to create a reliable flood management plan system to assist with climate change modelling.
\end{abstract}

Keywords: theorectical flow direction modell, flood, Sajó river

\section{Bevezetés}

A Sajó-folyó alsó szakaszán, a 08.06/7 ôrjáráson belül több alkalommal észlelte az ôri állomány, hogy a folyó bal partján, III. fokot meghaladó árhullám esetén a 67+000 folyami kilométer térségében és a Kis-Sajó, Boldva külterület irányából időszakos vízfolyások érik el a Szirmabesenyő-Sajóvámos közötti közút átereszét. Az összegyült víz áthalad a környezö települések közti területen, és mielőtt a Sajó folyóba ömlene, eléri az Arnót külterületen megépített árvízlevezető vápát (1. ábra). Mivel gyakran érint szántóföldi müvelés alatt álló területeket, így a terepviszonyok miatt, nem vagy csak nagyon nehezen lehet megfigyelni a jelenséget.

A 2020. évi októberi árhullám alkalmával, újra megjelent ez az időszakos vízfolyás, kb. 4 napos „élettartammal”, így volt esélyünk nyomon követni annak vonulását. A több napig tartó vízutánpótlást magyarázná a Sajó közelsége, ám a terület magasabban helyezkedik el a folyótól, így valószínübb, hogy 
a Kis-Sajó vízfolyás Sajósenye-Sajóvámos közötti szakasza felől kapja azt, ám a korábban említett nehézségek miatt ez nem teljesen bizonyított. A jelenség magyarázatára több térképi állomány alkalmazása mellett, az Arcmap 10.7.1 térinformatikai program hidrológiai eszköztárának segítségével létrehoztam egy elméleti lefolyásmodellt, amely segíthet feltárni az élővízfolyással való kapcsolatát.

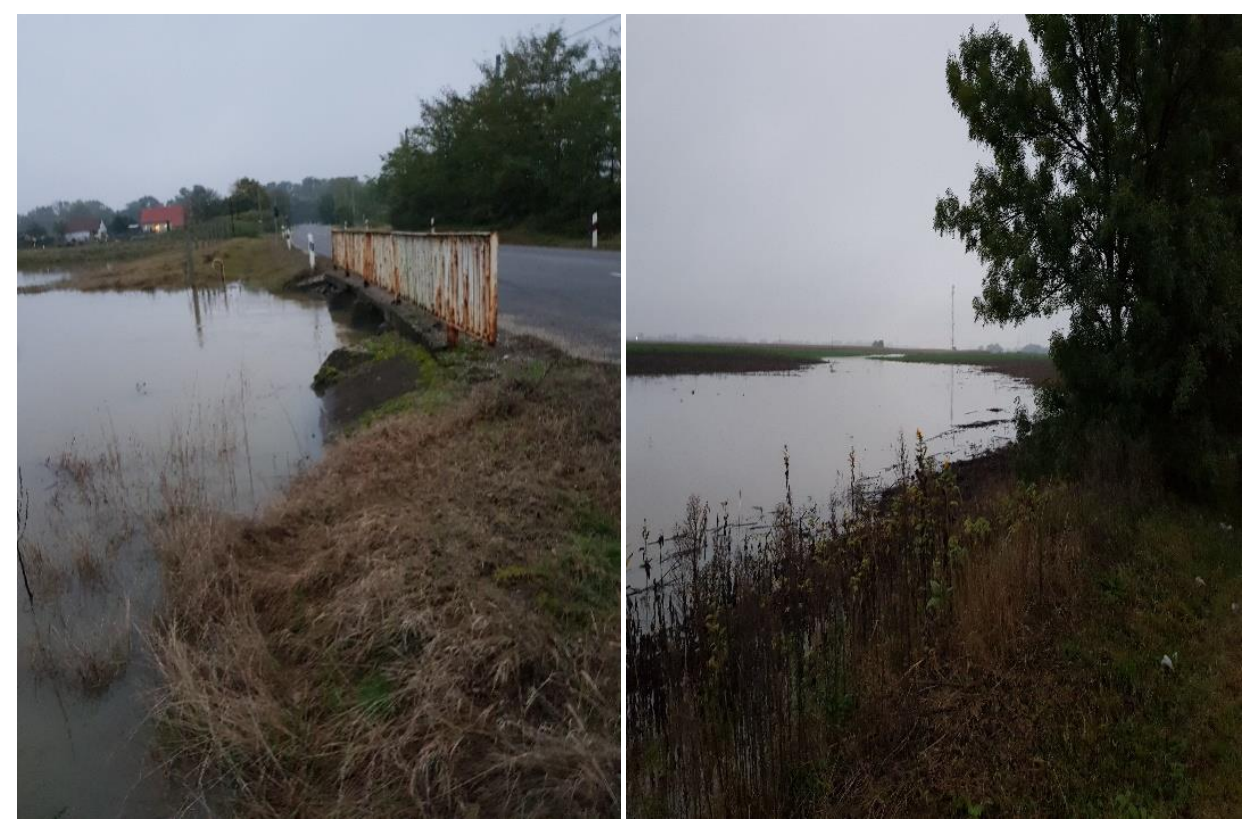

1. ábra. Az időszakos vizfolyás tetőzö állása a Szirmabesenyőt Sajóvámossal összekötő közútról

\section{A terület természetföldrajzi leírása}

A terület a Sajó-Hernád sík elnevezésủ kistáj, északi részén található (2. ábra). A területet homogén új holocén folyóvízi üledékek fedik, így talajai is alluviális üledéken képződött réti, öntés talajok (nagyrészt vályog fizikai féleséggel), amelyek közepes víznyelésủ és víztartású, általánosságban jó víztartó képességgel jellemezhetők [1]. A terület hullámos felszínü, kis relief energiával jellemezhető, felszínét a Sajó és a Kis-Sajó vízfolyások alakították ki és befolyásolják napjainkban is.

A táj jellemző növényzetét a Sajó folyó ezen szakaszának árterein füz-nyár ligetek, a magasabb térszíneken tölgy-kőris-szil ligetek jelentik. Ma a táj túlnyomó része mezőgazdasági terület, nagytáblás szántóföldi kultúrákkal. A puhafás füz-nyár ártéri erdők gyakorlatilag csak a vízfolyások keskeny sávján maradtak meg (fehér füz - Salix alba, csöregefüz - S. fragilis, elvétve fekete nyár - Populusnigra - idős példányai), állományaikat sokfelé nemesnyárasokkal váltották fel, tömegesek az özönfajok. A táj jellegzetességei a nagy kiterjedésű kavicsbányatavak, a bolygatás intenzitásától és a felhagyás időtartamától függő másodlagos növényzettel [1].

A terület sokévi átlagos havi középhőmérsékleteit tekintve elmondható, hogy a leghidegebb hónap a január, míg a legmelegebb a július. Az évi közepes hőingás $22,9{ }^{\circ} \mathrm{C}$, a napsütéses órák éves összege átlagosan 1944 óra, de évenként nagy változékonyságot mutat. Megfigyelhető a napfénytartam jellegzetes évi menete, a nyári hónapokban van a maximuma (havi 230-250 óra), míg november-január időszakban a minimuma, havi 40-60 óra [2]. 


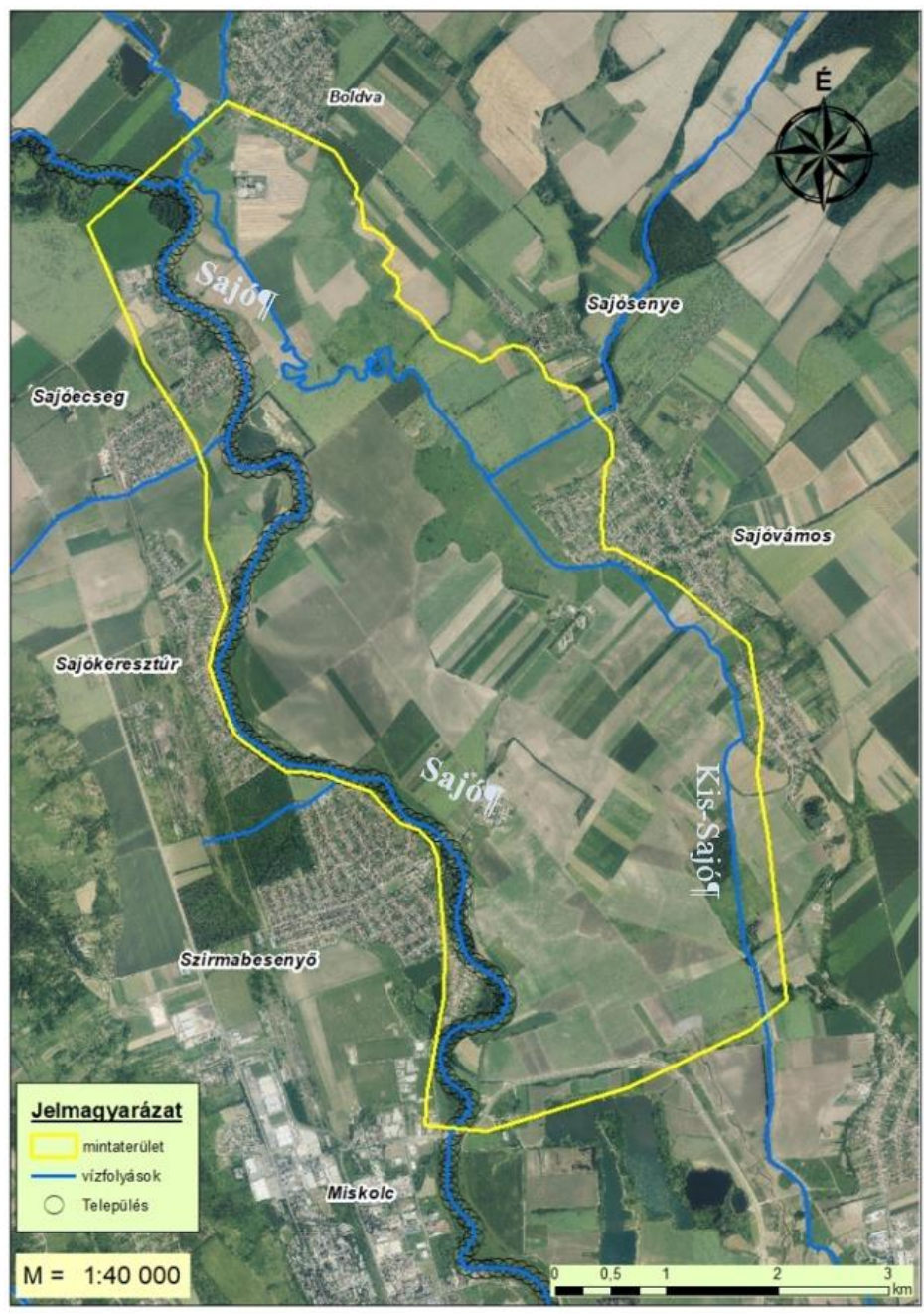

2. ábra. A mintaterület térképe

Az átlagos évi csapadékösszeg $593 \mathrm{~mm}$, mely jellegzetes évi menetet mutat, a nyári félév csapadékosabb, míg az ősz és a tél szárazabb. A legkevesebb csapadék január-februárban hullik, a legcsapadékosabb hónap pedig - közel négyszer akkora összeggel - a június. 2020 évben a június az átlagosnál kissé melegebb és - főképp hazai területen - attól lényegesen csapadékosabb időjárást hozott (3. ábra). A száraz tavasz után a havi csapadék mennyisége 1,5-2,5-szerese volt a megszokottnak [2].

Az idei nyárról elmondható, hogy nagyobb hőhullámoktól mentes, de összességében az átlagostól kissé melegebb és számottevően csapadékosabb volt, mint az a sokéves átlagok alapján várható volt [3].

A területen megjelenő időszakos vízfolyás kialakulásában nagyban közrejátszott az, hogy a döntően csapadékos időjárás folytatódott összel is, így szeptember végére, október elejére már a talajban a felső 30-40 cm teljesen át volt ázva. A talaj komplex tulajdonságai révén komoly tényezőt jelent a lefolyás vizsgálatok során. A jelen kutatás szempontjából a talajfelszín víztelítettsége (amelynek értéke arányosan csökken a vízbefogadó képességével), valamint talajnedvességi (pF-görbékkel kifejezhető) állapota döntő [4]. Viszont a területen mintavételezésre és egyéb talajtani vizsgálatokra nem volt időnk, így a lehetőségek szerinti legjobb módszertant alkalmaztuk. 


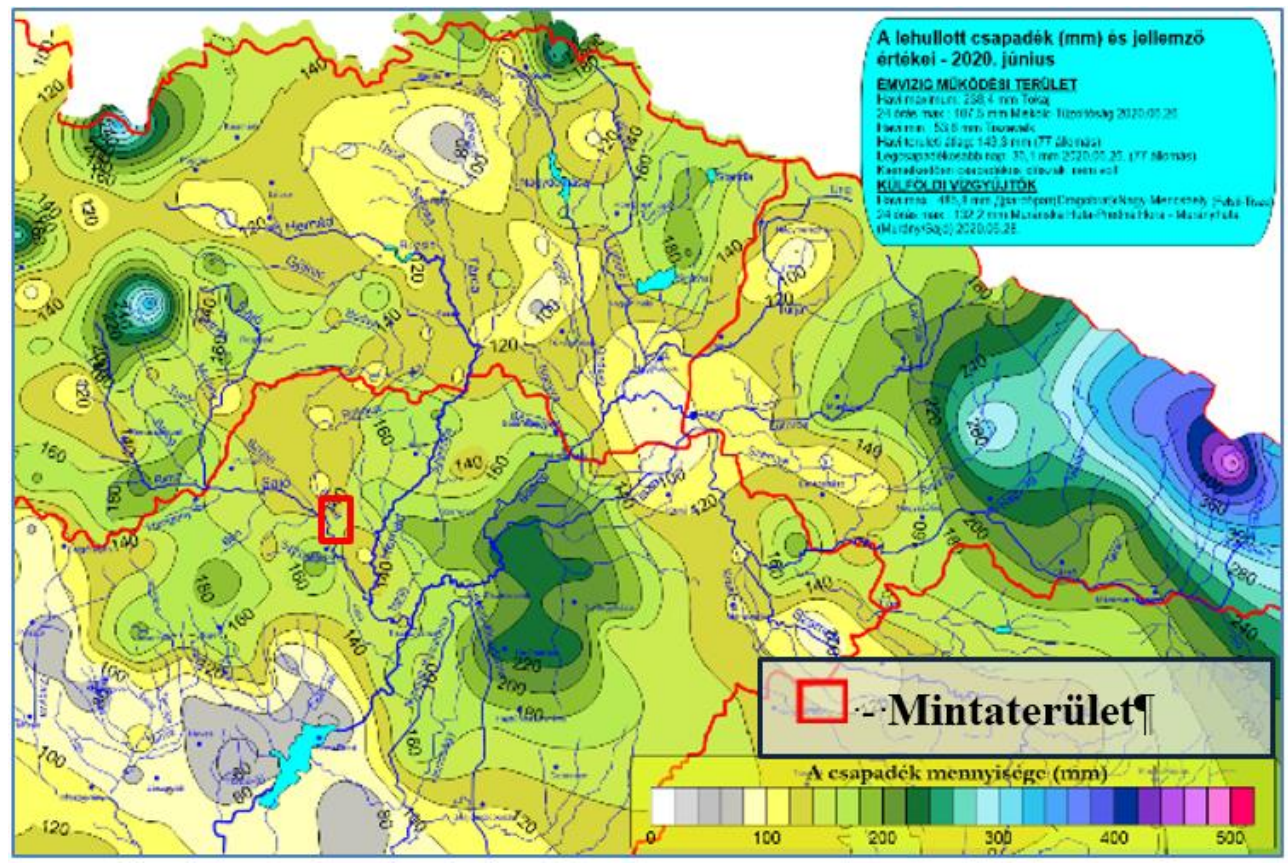

3. ábra. 2020 júniusának az átlagos értéket lényegesen meghaladó havi csapadékmennyiségei, forrás: EMVIZIG

\section{Anyag és módszertan}

A rendelkezésre álló 5 méteres felbontású domborzatmodell állományán elsőként, az esetleges terepi egyenetlenségek kitöltéséhez szükséges „fill” (kitöltés) parancsot alkalmaztam, ezzel kialakítva a további modulok futtatásához és későbbi elemzésekhez legjobb felületet (4. ábra). Ezt követően a „flow direction” (lefolyási irány) és a „flow accumulation” (lefolyás összegyülekezés) eszközök segítségével meghatároztam a domborzat modell celláihoz tartozó magasság értékek alapján a lefolyás irányát és az összefolyások helyeit, megkapva ezzel a terület elméletilefolyás hálózatának teljes képét. Az összegyülekezési állomány további műveleteivel (Stream order/Stream to feature) a teljes hálózat exportálható vektoros állományként, valamint a „basin” (medence) és „,watershed” (vízválasztó) paranccsal meghatározható egy adott területhez tartozó vízgyüjtő és vízválasztó területe [5].

A kapott állományon további osztályozásokat hajtottam végre, melynek végeredményeként I. II. és III. rendủ elméleti lefolyás csoportokat alakítottam ki a mintaterületre vonatkozóan. Erre azért volt szükség, mert az alkalmazott modell I. rendủ elméleti lefolyás csoportjai (jelen esetben a II. rendủek bizonyos szakaszai is) megegyezhetnek a valós természeti vízfolyásokkal (pl.: Sajó-folyó, Kis-Sajó), a vizsgálat szempontjából a II. és III. rendủek tartalmazhatnak használható információkat.

Fontos megemlíteni, hogy a kapott elméleti lefolyás modellben a pixelek értékei, jelen esetben, dimenzió nélküli számok nem pedig tengerszint feletti magasságban, csapadékmennyiségben, vízhozamban stb. értendő mennyiségek. Minél nagyobb felbontású egy domborzat modell raszteres állománya, annál több pixel érték juthat egy-egy cellára a kifolyási pontban, például torkolatokban vagy völgytalpaknál [6]. Így ezek a számok jobbára a jelenség volumenére engednek következtetni, de kétségtelenül hasznos információt tudnak szolgáltatni a vizsgálatok során, így a módszer elengedhetetlen kelléke az időszakos vízfolyások vagy a villámárvizek vizsgálatainak. 


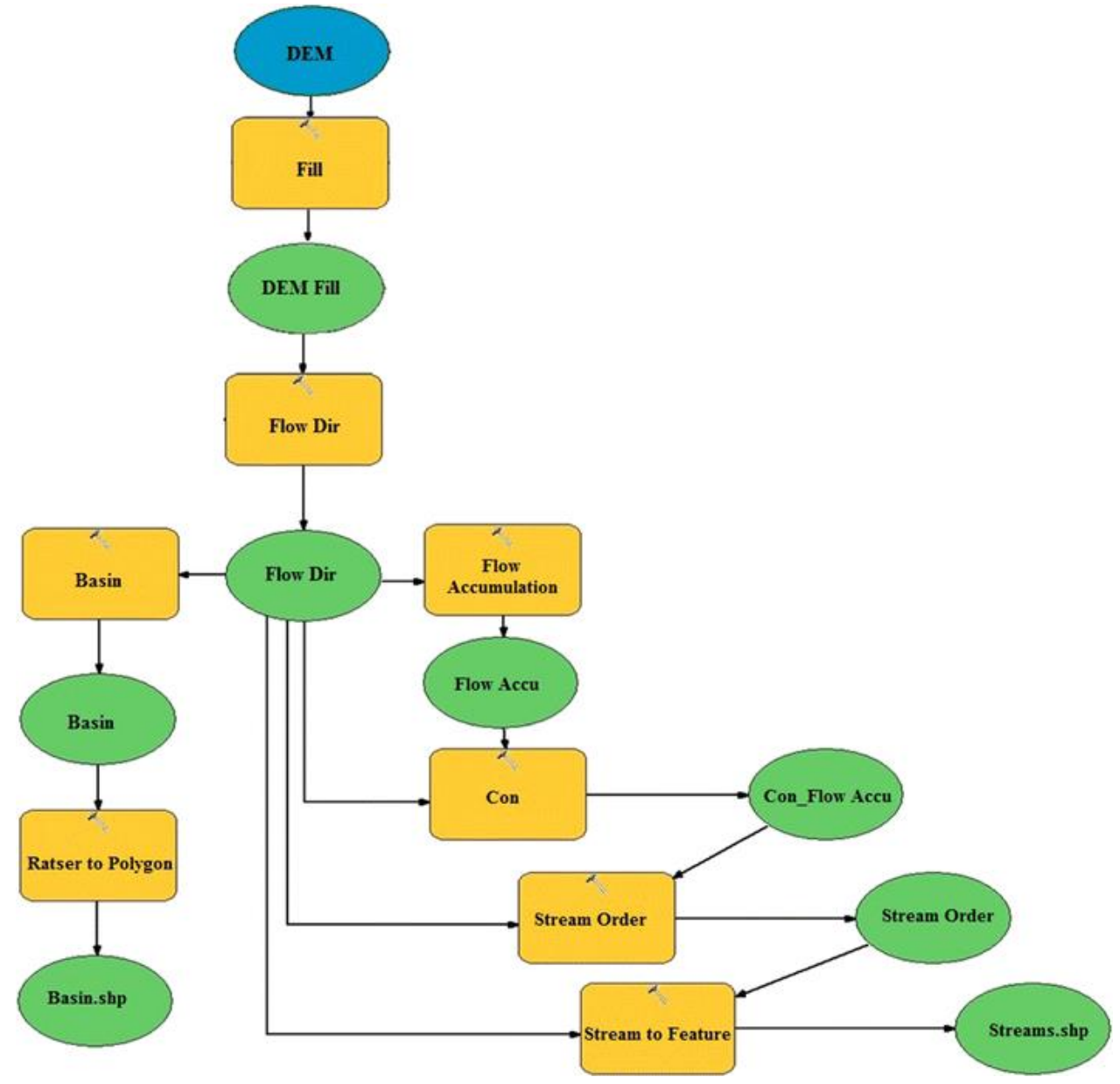

4. ábra. Az elméleti lefolyásmodell folyamatábrája, forrás: pro.arcgis.com

Az elkészült térképen (5. ábra) látható, hogy a mintaterület déli határánál számos kisebb III. rendü vízfolyás csoport (fehér) csatlakozik be 2 db II. rendü (világoszöld) időszakos vízfolyásba, amely végül eljut a Felsőzsolca árvízlevezető vápa felső részéhez. Ezek vízhozama az időjárási körülményektől, az árhullám nagyságától és a beszivárgás mértékétől függhet. A vizsgálatunk tárgya a pirossal jelzett időszakos vízfolyás, amely több csoportot foglal magában.

A domborzatmodellből származtatott elméleti lefolyás modell segítségével kirajzolódik a lefolyás hossza, amely közel 7,5 km. A lefolyás és domborzatmodell összevetése alapján megállapítható, hogy nem rendelkezik közvetlen kapcsolattal sem a Sajó, sem a Kis-Sajó vízfolyásokkal. Így arra a kérdésre, hogy az időszakos vízfolyás honnan kapja a vízutánpótlást, nem adható válasz. Behatóbb elemzéshez, a terepi tapasztalatokat és a domborzat modell elemzésében rejlő további lehetőségeit kell felhasználni, valamit meg kell vizsgálni a terület északi „forrásvidékét”. 


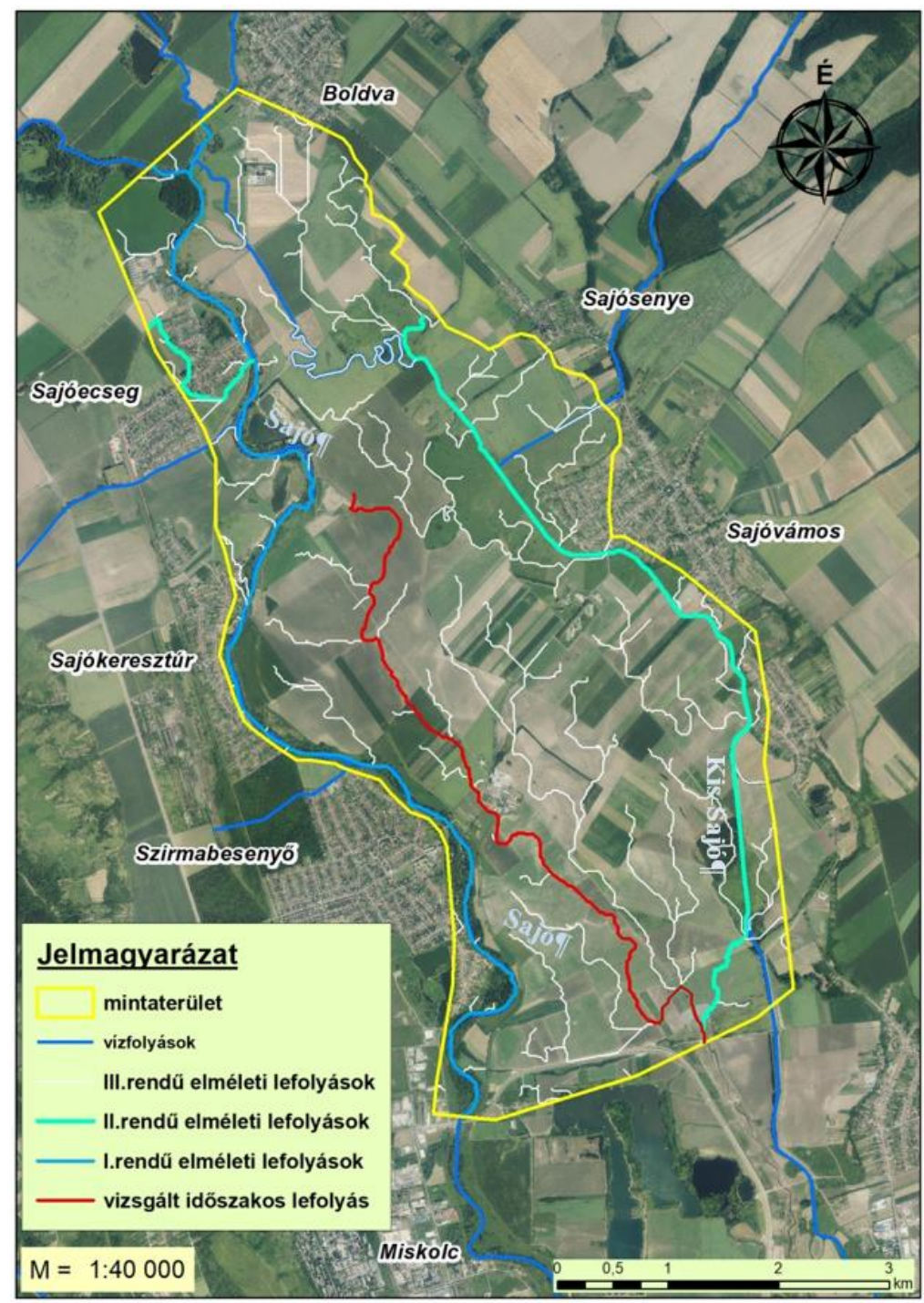

5. ábra. A Boldva külterület és Felsőzsolca árvízlevezetö vápa közötti területen megjelenö idöszakos vizfolyások térképe

A domborzatmodell (6. ábra) vizsgálata során kirajzolódnak a korábbi medrek, holtágak hálózatai, amelyek alkalmasak lehetnének a III. rendủ elméleti lefolyás csoportok összekapcsolódására, de ez nem mindenhol alakul ki. Viszont két lefolyási ág is található ezen a részen, amelyek potenciális lefolyáshálózatot alakíthatnak ki. Az egyik a pirossal jelölt „A” ág a korábban tárgyalt leghosszabb lefolyás kezdeti, északi területén található valamint a szomszédos rózsaszín színezésű „, $\mathrm{B}$ ” ág, amely déli irányba tart, majd hirtelen irányt váltva észak-keleti irányba fordul és eléri a Kis-Sajót a Sajóvámos közúti híd, felvízi elöterében. A két vízfolyás legközelebb a sárga körrel jelölt részen közelítheti meg egymást kb. 130 méterre, de nem érnek össze, vagyis lefolyási kapcsolat sem alakul ki köztük. Viszont elképzelhető, hogy megfelelő nagyságú árhullám esetén itt kerülnek összefolyásra, így hozzájárulhat az „A” ág lefolyásának felszíni vízutánpótlási útjához. 


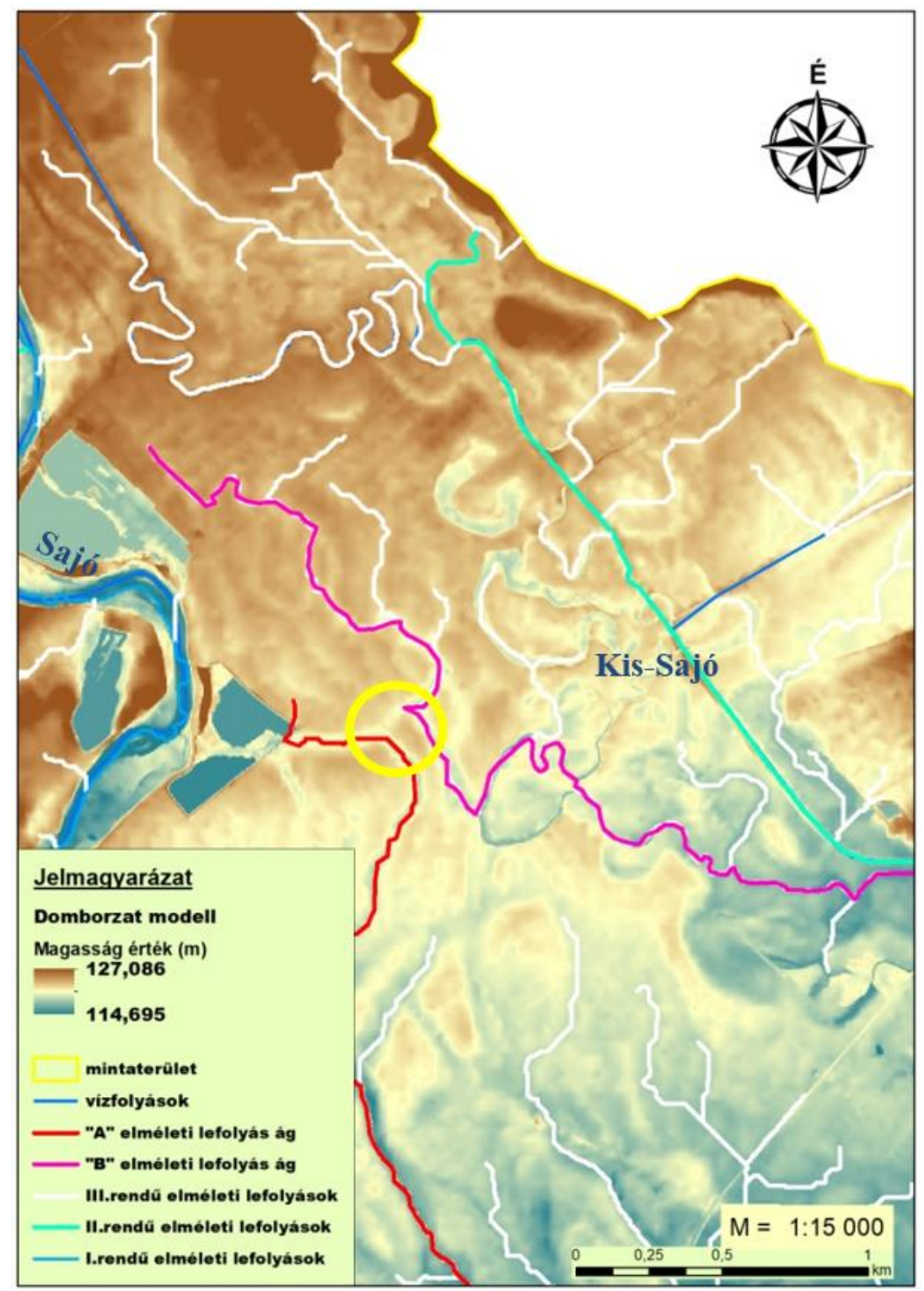

6. ábra. A mintaterület felső szakaszának térképe

Mivel a vizsgált terület egy része beleesik a rendelkezésünkre álló 2020 évi Sajó nagyvízi medrének lézerszkenneres geodéziai felmérésébe, így annak az eredményeként készült új domborzatmodellen ismét létrehoztam a lefolyásmodellt azonos módszertannal. A 7. ábrán látható, hogy a mintaterületen belül, az új felmérés narancssárgás árnyalatai nagyrészt fedik egymást a korábbi felméréssel, így többlet információt (pl: más lefolyási útvonalat) nem hozott a második lefolyásmodell. Az új domborzatmodell nagyobb részletessége $(0,5 \mathrm{~m})$ okán érdemes megvizsgálni a fekete körrel jelölt területet, amelyen belül a két ág távolsága jelentősen, a korábbi 137 méterről 35 méter alá csökken, megerősítve a korábban tárgyalt összefolyások lehetöségét. 


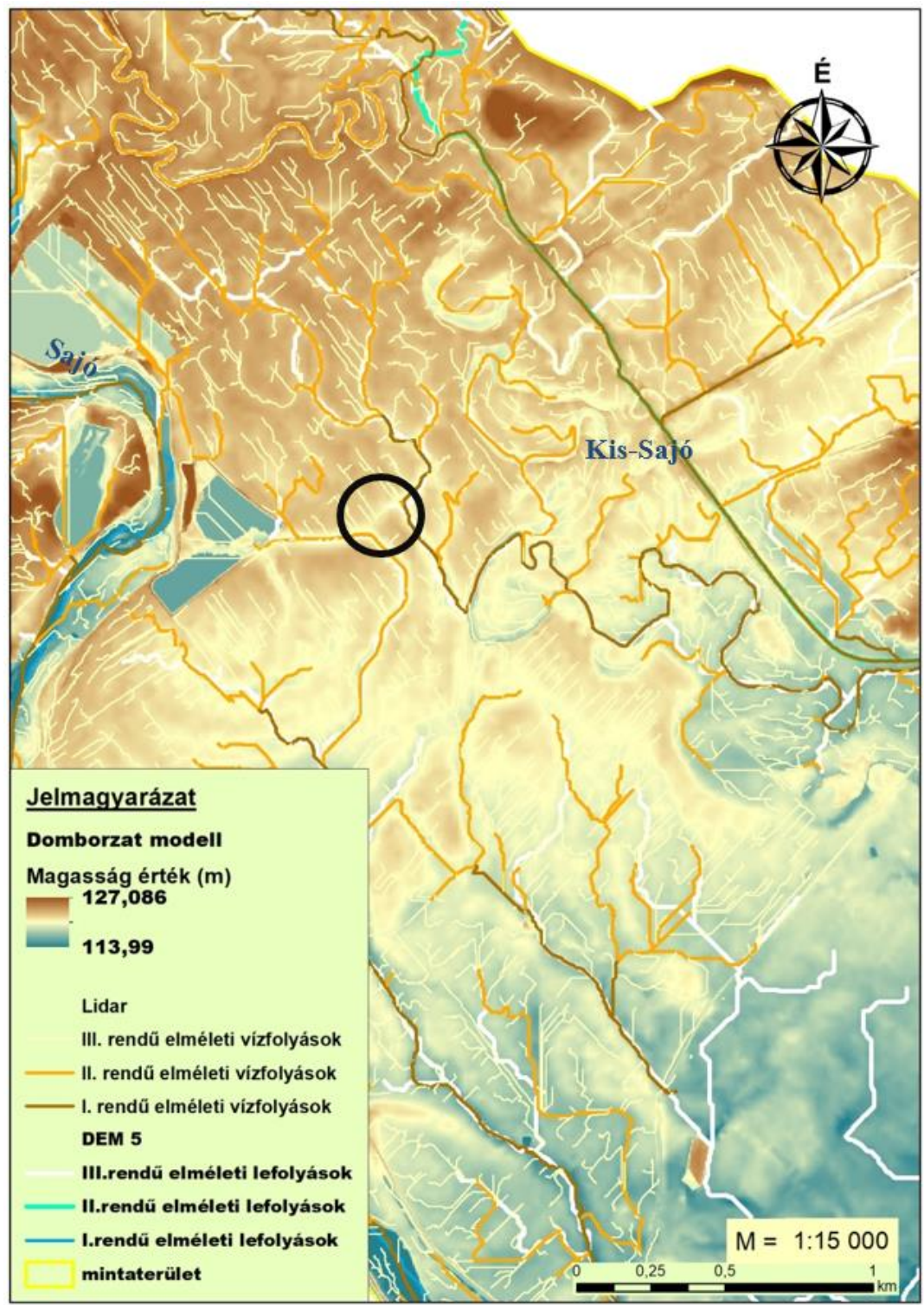

7. ábra. A két domborzatmodell segitségével létrehozott lefolyásmodell fedvényeinek térképe

\section{Eredmények}

A rendelkezésre álló adatok (domborzatmodellek, geológiai térkép, talajtani adottságokat leíró állományok) és a terepi bejárások, valamint a megfigyelések alapján több lehetőséget is felvázolhatunk az időszakos vízfolyás kialakulásával és annak vízutánpótlásával kapcsolatban.

Az egyik lehetőség szerint az északi irányból a Kis-Sajó medrének bizonyos fokú telítettsége mellett a korábbi holtágban is megjelenik a víz, majd a környező terület magasabb pontjait meghágva először a „B” elméleti lefolyási ágat telítve tovább halad dél, dél-nyugati irányba, ahol összekapcsolódásra kerül az „A” jelzésủ ággal, ezzel táplálva és fenntartva az időszakos vízfolyás intenzitását (8. ábra). 


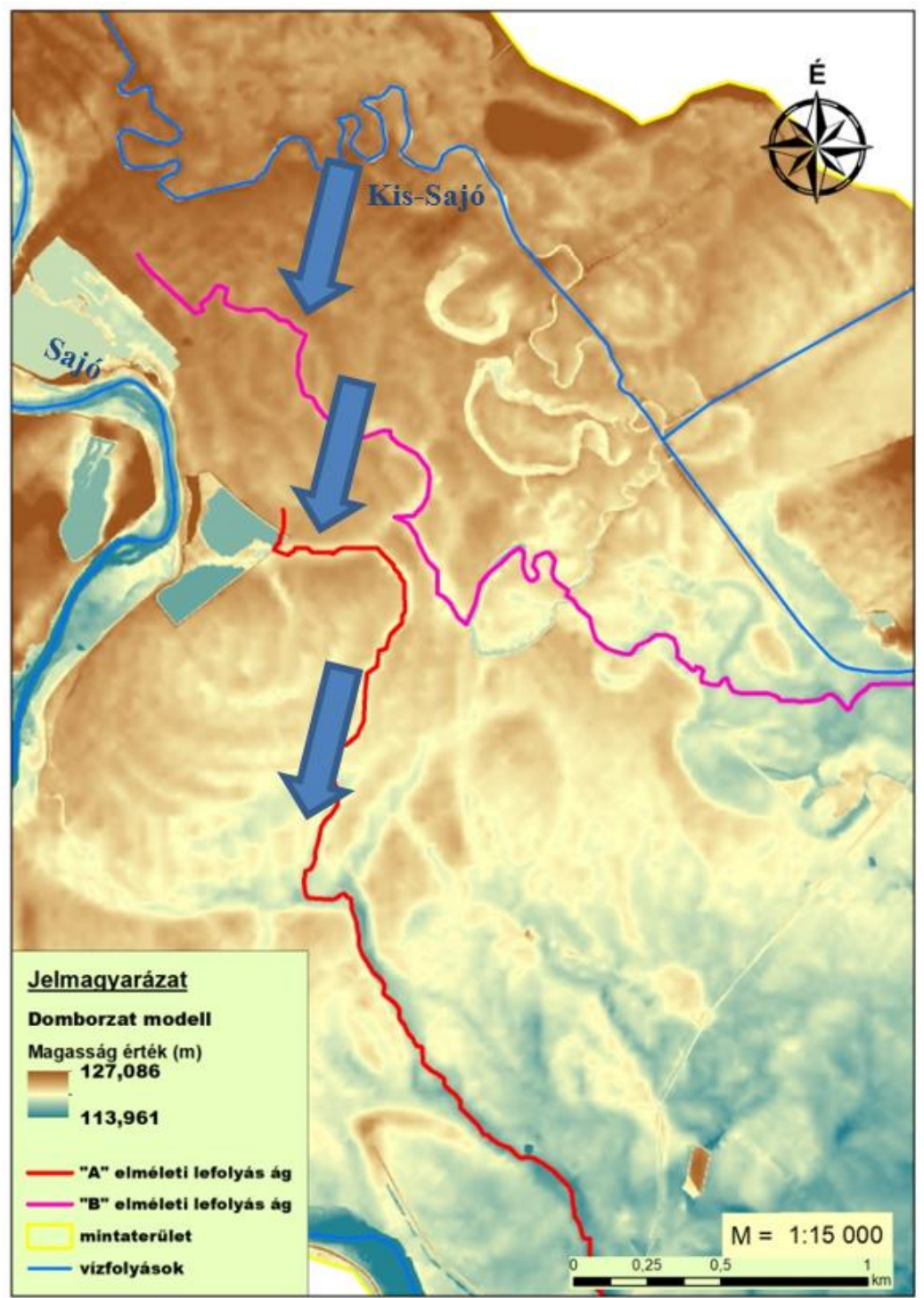

8. ábra. Az idöszakos vizfolyás lehetséges vonulásának és irányának térképe

A másik lehetőség szerint nagyobb árvizek esetén, a Sajó-folyó a 67+200fkm, bal partjánál magasság hiány következtében ki tud lépni a korábban tárgyalt területre, ahol eléri „B” elméleti lefolyási ágat. Majd a kavicsbánya tó mentén a legmélyebben fekvő területeken halad tovább déli irányba, ahol a két ág összekapcsolódásra kerül (9. ábra).

Ezt az álláspontot megerősítheti az ArcMap/ ArcToolbox/ Hydrology/ Basin parancssor segítségével kialakított állomány is, amelyet a vízválasztók lehatárolásához szoktak alkalmazni. A modul meghatározza, hogy egy adott pixel a lefolyási iránya (flow direction), még azonos vagy már egy másik vízgyüjtőhöz tartozik-e. Ezeket az adatokat a domborzatmodell magasság valamint lejtőszög értékei segítségével választja el [7]. Ebböl következik, hogy ennek az állománynak döntő szerepe lehet, mivel a korábbi állományok (domborzatmodell, lefolyás irány, lefolyás összegyülekezés) önmagukban nem alkalmasak egy ilyen kérdés megválaszolására. A kapott állományt a 10. ábrán láthatjuk. 


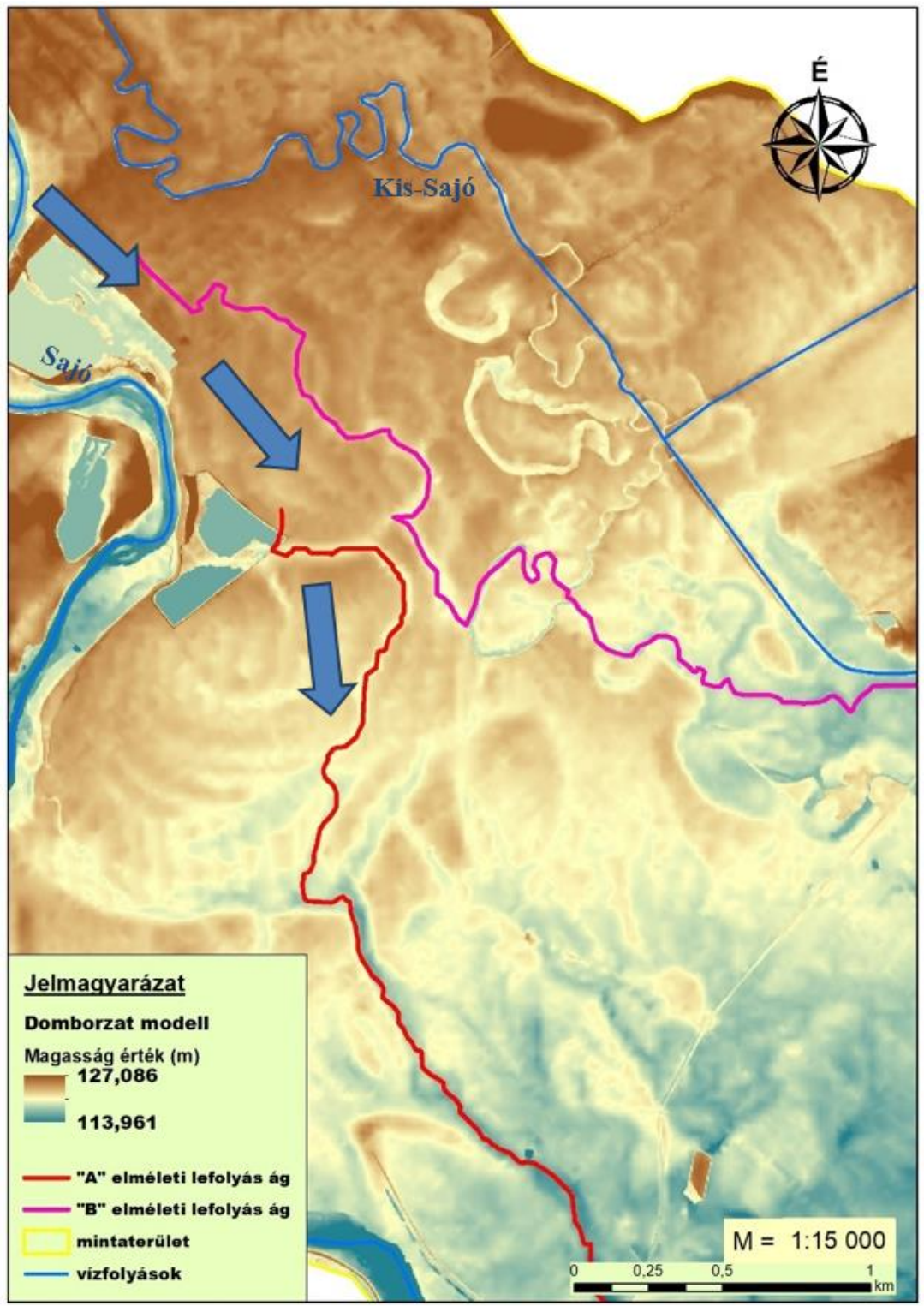

9. ábra. Az időszakos vízfolyás másik lehetséges iránya

A mintaterület esetében a Sajó folyóhoz a lila, a Kis-Sajó felöli rész a rózsaszín, a vizsgált időszakos vízfolyáshoz a sárga színekkel jelölt részvízgyüjtők tartoznak. A körökkel jelölt területek, az árhullám vízhozamának függvényében, a potenciális összefolyási területeket mutatja, a nyilak pedig a lefolyás irányát. Belátható, hogy a kérdéses területek a vízválasztókhoz nagyon közel, 50 méteren belül találhatóak, tehát kialakulhat köztük lefolyási kapcsolat. 


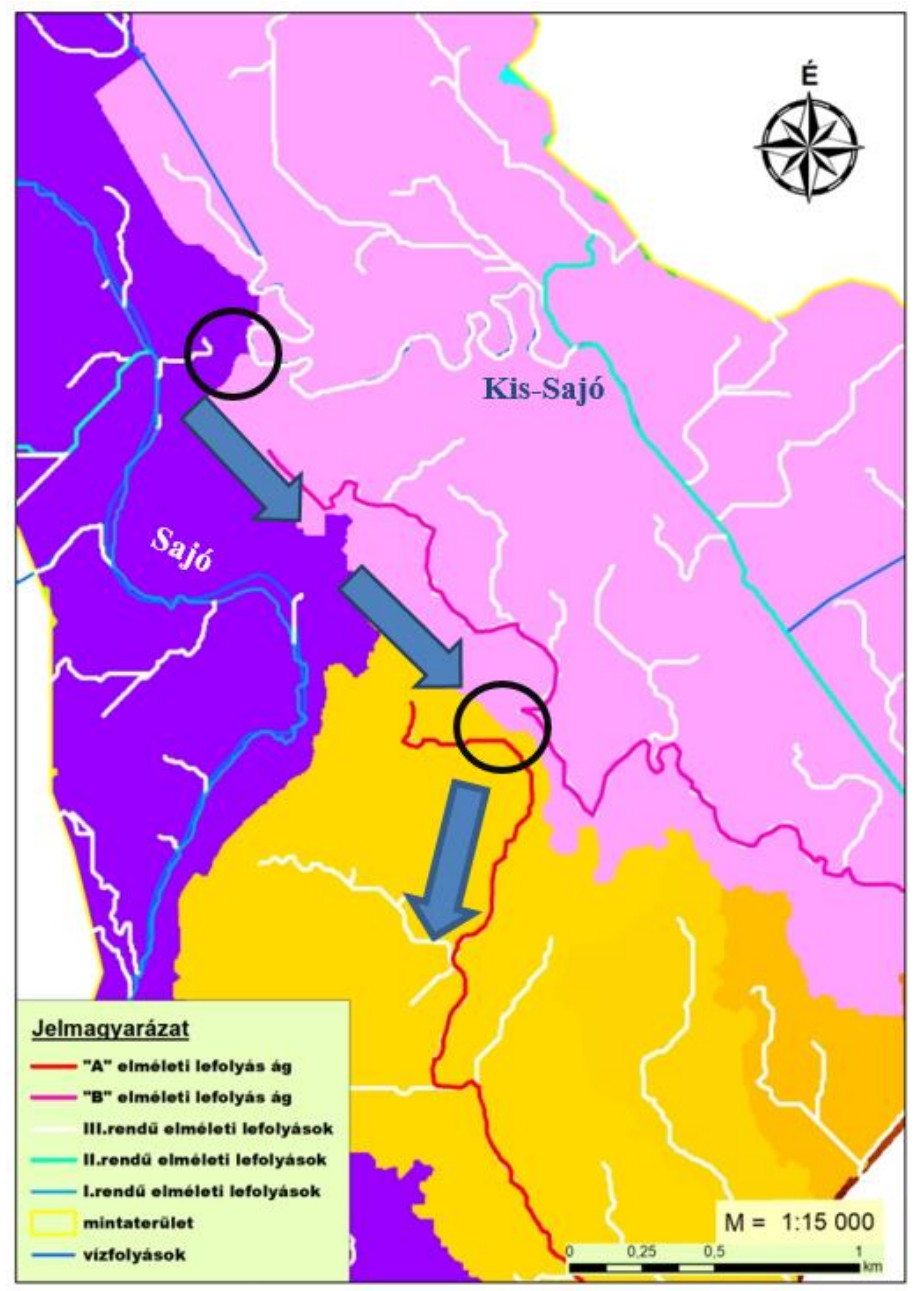

10.ábra. A mintaterületen található részvizgyüjtők térképe

\section{5. Összefoglalás}

Összességében elmondható, hogy a mintaterületen belüli viszonylagos kis szintkülönbségek (legnagyobb 2-3 m) ellenére a két domborzatmodell jól alkalmazható volt a lefolyásmodell kialakításakor, valamint eredményeik a vízügyi szakmában dolgozók számára érthető és értékes eredményeket hoztak. Mivel a csapadékos időjárás okán a maximális víztelítettségi állapotokról beszélhettünk, így az alkalmazott „,beton felszínü” lefolyás modellezés alkalmazása tünt a leghatékonyabb módszernek. A szakirodalom ezalatt azokat a lefolyási eseteket érti, amikor például víztelítettség, vagy beépítés (urbánus területeken) okán csekély mértékủ vagy egyáltalán nincs felszíni beszivárgás, így a lehullott csapadék ellenállás és beszivárgás nélkül folyik le egy vizsgált területen. Az eljárás során kapott eredmények nagy segítséget nyújtottak a jelenség értelmezésében és kialakulásának megértésében. A vizsgálatok alapján elmondható, hogy a mintaterület kialakításában mind a Sajó, mind a Bódva vízfolyások aktívan szerepet játszottak, így nem elképzelhetetlen, hogy a két elméleti lefolyási irány kombinációja adhat valós képet a jelenség kialakulásáról. 
A továbbiakban az ÉMVIZIG müködési területén a korábban tárgyalt időszakos vízfolyást, az elkészített modelleket szem előtt tartva figyelemmel fogjuk kísérni. A cikkben röviden bemutatott eljárást szeretném a mintaterületemen is alkalmazni, hiszen a rendelkezésre álló domborzatmodellek jó hátteret tudnak szolgáltatni a villámárvíz lefolyásának vizsgálataihoz is.

\section{Köszönetnyilvánítás}

A cikkben ismertetett kutató munka az EFOP-3.6.1-16-2016-00011 jelü „Fiatalodó és Megújuló Egyetem - Innovatív Tudásváros - a Miskolci Egyetem intelligens szakosodást szolgáló intézményi fejlesztése" projekt részeként - a Széchenyi 2020 keretében - az Európai Unió támogatásával, az Európai Szociális Alap társfinanszírozásával valósul meg.

\section{Irodalom}

[1] Dövényi, Z.: Magyarország kistájainak katasztere, második kiadás, 2010, 876 p.

[2] https://www.met.hu/eghajlat/magyarorszag_eghajlata/varosok_jellemzoi/Miskolc/

[3] ÉMVIZIG: Tájékoztató BAZ megye ár- és belvizvédelmi helyzetéröl II. félév, 2020, 15 p.

[4] Stefanovics, P., Filep, Gy., Füleky, Gy.: Talajtan, Mezőgazda Kiadó, Budapest, 1999, 470 p.

[5] Hiep-Thuan, D., Sébastien, L., Emmanuel, M.: Parallel computing flow accumulation in large digital elevation models, Internation Conference on Computational Science, ICCS 2011,10 p.

[6] Balatonyi, L: Árvizhozam előrejelzés optimalizálása középhegységi és dombvidéki vízgyüjtökre, Pécs, 2015, 42 p.

[7] https://desktop.arcgis.com/en/arcmap/10.3/tools/spatial-analyst-toolbox/basin.htm 